\title{
'In the sight of all': Queen Elizabeth and the Dance of Diplomacy
}

In a well-known painting from the sixteenth century, a man and woman dance the volta, one of the most popular and energetic dances of the Renaissance (fig.1). Although it is unclear whether the picture is set in France or England, or whether the dancers are Queen Elizabeth and Robert Dudley, the man and the woman are certainly significant members of a glittering court, important enough for all to look upon, and important enough to be recorded in a painting. Whoever the man and woman are, whatever the setting, the very composition of the picture literally and figuratively points to the unquestionable significance dancing occupied in early modern court life. $^{1}$

During the Renaissance dancing was for all classes more than a popular pastime; it was a cultural practice deeply integrated into any celebration or significant event. Dancing was central to social and political participation, and often success: being noticed in a brilliant performance at court could lead to monetary or political gain. Such a recognition was certainly the case with Christopher Hatton who, according to Robert Naunton, 'came to the court ... by the galliard, for he came thither as a private gentleman of the Inns of Court in a masque, and for his activity and person (which was tall and proportional) taken into the Queen's favor.' ${ }^{2}$ In his 1603 masque, The Satyr, Ben Jonson recreates such a moment at court. 'They came to see, and to be seen', he writes, 'And though they dance before the Queen, / There's none of these doth hope to come by / Wealth to build another Holmby', Hatton's estate. ${ }^{3}$

As this often-cited incident of Hatton's good fortune reveals, dancing was more than just a pleasing entertainment that helped pass an evening at court - it carried political implications in every gesture. Discussing the court masque, Clare McManus describes dancing as the 'bodily performance of power, the representation of the power structures of the court in 


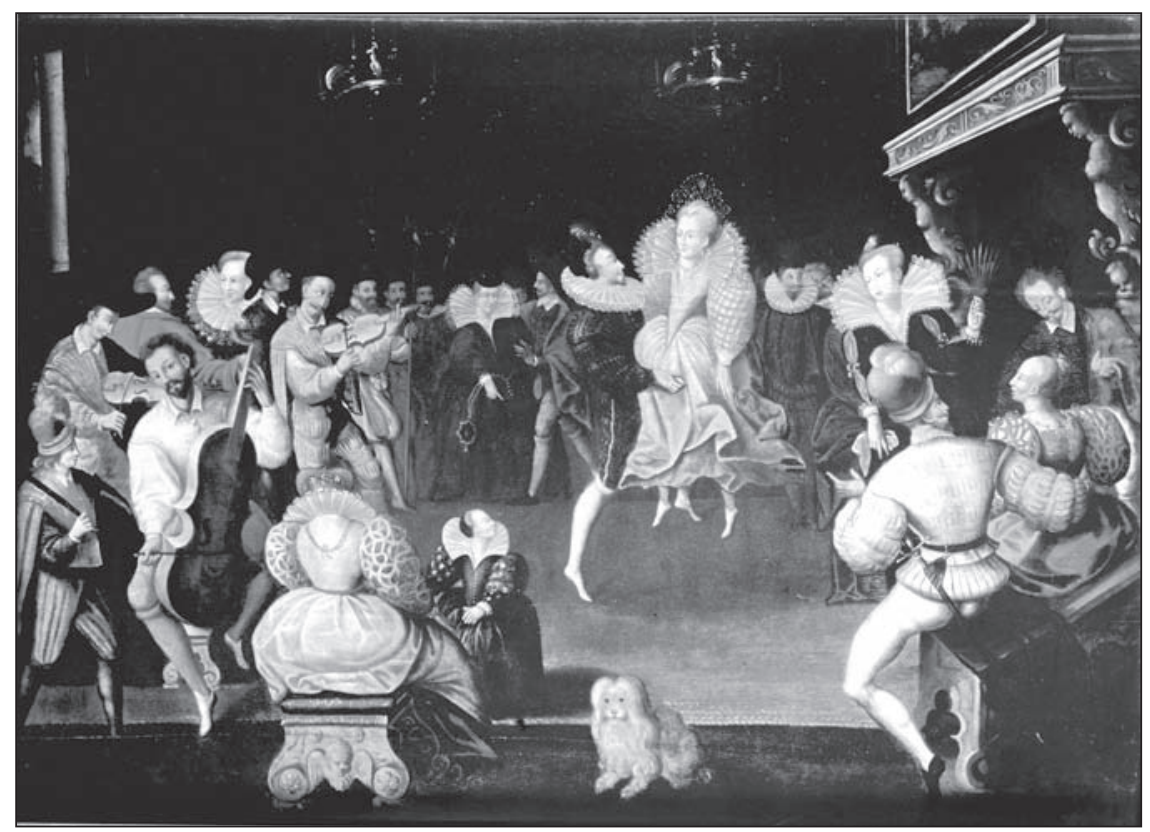

Figure 1. Queen Elizabeth I Dancing La Volta with Robert Dudley, by kind permission of Viscount De L'Isle from his private collection at Penshurst Place, Kent, England

movement'. ${ }^{4}$ Jennifer Nevile notes how politically charged all elements of a dance performance within a court spectacle or masque could be, including 'who danced with whom, the order in which they danced', the position of the 'king's or queen's chair within the performance space', and how crucial all these factors were in representing 'power in the court, and in the wider society. ${ }^{5}$ Perhaps one reason dance seems so perfectly suited to politics is that, according to Barbara Ravelhofer, it is a 'non-verbal lingua franca', 'not affected by language boundaries' and so immediately understood by all who watch. ${ }^{6}$

The issue of dance and politics in the early modern period has been the subject of several studies, but much of that scholarship focuses on court spectacles such as the ballet de cour and the masque in the seventeenth century. ${ }^{7}$ While the masque was certainly an entertainment form in England under Henry VIII and Elizabeth, it reached its height in the seventeenth century with Anne of Denmark, Henrietta Maria of France, and the artistry of Ben Jonson and Inigo Jones. The richness of performance venues for women in this later period - allowing them to play significant roles in the masque, 
as actors and dancers - coupled with the predominance of scholarship on court masque and spectacle is perhaps in part responsible for the fact that less attention has been paid to dancing at the Elizabethan court. And while the virtuosity of Queen Elizabeth's dancing is often cited, the political implications of her dancing have received less analysis. ${ }^{8}$

In this essay I want to shift the focus to Elizabeth and her dancing, and away from the confines of the masque. While I do not intend to discount the importance of the masque, I want to concentrate on Elizabeth in order to understand the particular strategies she used to manipulate dance for political and diplomatic gain. Sophie Tomlinson, in distinguishing theatrical performance opportunities for women in the Elizabethan and Stuart periods, proposes that Elizabeth's 1586 statement that 'princes' are 'set on stages, in sight and view of all the world', is a clear indication of how she 'conceived of herself as an actor'. Tomlinson continues that 'no matter how artfully' Elizabeth may have constructed roles for herself, she was confined by the 'all-pervasive' 'political role' that she had to play 'first and foremost' as 'monarch'? This assertion is important because it articulates a strategy of the queen's. While Elizabeth did not perform in court masques to the extent and in quite the ways that Anne or Henrietta Maria did, often playing roles other than their own, I would argue that Elizabeth was not limited by her role as monarch. Rather, Elizabeth exploited her role as queen, using her persona, her performative abilities, and her dancing as part of her political apparatus. Part of Elizabeth's general strategy, I suggest, was to make her persona the centre of any discourse.

As we know, Elizabeth was a master rhetorician, but her mastery of rhetoric was not limited to the verbal. When the French dance master, Thoinot Arbeau, famously remarked in 1599 that dancing was 'a kind of mute rhetoric', in which the dancer can make himself 'understood by his movements and persuade the spectators that he is gallant and worthy to be acclaimed, admired and loved', he touches on one of the express purposes of dancing. ${ }^{10}$ An examination of the convergence of these two rhetorics - the language of dance and the dance of language - reveals how well Elizabeth managed these rhetorics to 'persuade' those observers that she was not only a great dancer and a brilliant speaker, but also a youthful, competent, in-control, and virtuous female ruler.

While I will refer to memoirs and recollections from members of Elizabeth's court, in discussing the rhetorics of dance and language in the queen's performances, I will focus on three narratives by foreigners, all of whom were 
on diplomatic missions to England: the Scottish ambassador James Melville in 1564, the French ambassador André de Maisse in 1597, and the Italian Virginio Orsini in 1600. Often cited because they mention Elizabeth's dancing, these records have not been carefully analyzed for their narrative qualities or for what they reveal about the queen's strategies around dancing. Each narrative also records Elizabeth's conversations about her dancing and each reveals how Elizabeth could often blend the two rhetorics. All of these foreign visitors, regardless of their missions, recorded their encounters with Elizabeth, not only for their patrons and lords but also for their own personal memoirs. And Elizabeth, aware that these occasions of dance and conversations would be recorded, consciously staged and manipulated both the actual occasions of her dancing and discussion about her dancing talents in order to enhance her reputation as a great ruler, simultaneously quelling any ideas foreign rulers had about her weakness or potential demise. In all of these narratives Elizabeth appears in control, the primary actor who brilliantly exploits her role as monarch, but is not limited by it.

Clearly, Queen Elizabeth of England was not alone in her desire to incorporate dancing into the political fabric of the court. Other European monarchs, such as Catherine de Medici of France, recognized the importance of dance, performance, and spectacle in representing political prestige and power. Apparently, when Catherine came to power in 1563, dance 'became a courtly craze'; and in 1565 the English ambassador, Thomas Smith, reported that 'there is nothing but dancing and mummeries' at the court. But dancing and entertainments like masques were 'not innocent occasions'; rather they reflected the 'strength' of the French court, bolstered the country's 'reputation', and kept threatening noblemen in check. Catherine's son, Henri III, continued such entertainments and was such a devotee of dancing that in 1579 his doctors thought that too much dancing had brought on a severe ear infection. ${ }^{11}$

Like Henri following his mother, Elizabeth literally followed in the footsteps of her father, Henry VIII, also an accomplished dancer who used dancing to negotiate the complexities of court life. In 1510, for example, Edward Hall reports Henry performing in a 'mummery' with other lords, beautifully dressed in 'crimson and purple satin', and performing so wonderfully that the court visitors and the queen 'much praised the king'. In 1514 the Milanese ambassador reported that Henry, 'dancing in his shirt and without shoes', was able to do 'wonders' and leap 'like a stag' with the women. ${ }^{12}$ Both of these examples reveal the visual and physical advantages dancing provided 
Henry to display his wealth, power, and sexual prowess, not only to his own court members, but also to the Milanese ambassador and other visitors.

Many reports exist of dancing at Elizabeth's court, as well as of her own dancing. During Christmas 1572, Sir Thomas Smith, the queen's principal secretary, wrote to a friend from Hampton Court, 'If ye would know what we do here, we play at tables, dance and keep Christmas'. In June 1559, Paolo Tiepolo, the Venetian ambassador, reported that the French ambassador had been 'more than once banqueted and entertained' with 'dances and hunting. Tiepolo later noted that the 'Queen's daily arrangements are musical performances and other entertainments', and Lupold von Wedel, who visited the court in 1585 during Christmas, reported a dance of 'slender and beautiful' women, 'magnificently robed'. 13

Descriptions of Elizabeth dancing, and as Giovanni Michiel, the Venetian ambassador, reported, 'frequently showing herself in public', date from the very beginning of her reign. At one of the dances to celebrate the coronation, Elizabeth was reported to have 'performed her part', with the 'Duke of Norfolk being her partner (capo) in superb array. ${ }^{14}$ During his 1581 visit to England, François, duke of Alençon, was apparently greatly impressed by Elizabeth's performance in 'matters of princely pleasure, as dauncing, musicke, discoursing', and 'perfection of many Languages'. ${ }^{15}$ Even when she was older, Elizabeth continued to dance. In a 1589 letter, John Stanhope, a gentleman of the privy chamber, calms any fears about Elizabeth's health, when he writes to Lord Talbot 'the Queen is so well I assure you, six or seven gallyards in a morning, besides music and singing is her ordinary exercise. ${ }^{16}$ André de Maisse reported in 1597 how she continued to take 'great pleasure in dancing and music', adding that 'without doubt she is a mistress of the art, having learnt in the Italian manner to dance high'. And in 1599, in perhaps a less than completely flattering comment, a Spanish visitor wrote that he had witnessed 'the head of the Church of England and Ireland ... in her old age dancing three or four galliards'. ${ }^{17}$

Dancing has its rewards, clearly, as a form of entertainment, diversion, and exercise, as the galliard example shows. In fact, in listing some of the benefits of dancing, Thoinot Arbeau calls it the perfect exercise for females who typically live 'sedentary lives' and are not 'free to take walks, or go here, there and everywhere'. ${ }^{18}$ Getting exercise was certainly a reward for women living more restricted lives at court, but dancing was also the chance to perform 'in the sight of all', and, as Jonson notes, to 'see and be seen'. As a performance art, dancing in any Renaissance court was certainly about 
being on display. As John Schikowski wrote in the 1920s, 'the end of dancing was ... the exhibition of one's own person'; the reason one danced 'was to show dignity, gracefulness and the exact knowledge of rules of decorum and propriety'. ${ }^{19}$ Schikowski's use of the word 'exhibition' seems particularly revealing, as the example of Hatton shows. In his 1530 Ricordi, the Italian humanist Francesco Guicciardini noted that dancing could lead to 'the favor of princes, and sometimes becomes the beginning of the reason for great profit and high honors'. When dancing at court, the display of 'dignity', grace, and 'decorum' were all in service of honour and profit. ${ }^{20}$

Paolo Tiepolo, commenting on the daily performances of music and dancing at the court, notes how Elizabeth 'takes marvelous pleasure in seeing people dance'. More than one observer corroborates this practice. De Maisse, too, notes how the queen enjoys seeing her 'Maids dance', following their cadence and rebuking 'them if they do not dance to her liking'. Von Wedel describes how Elizabeth both observed the dancing and used it as a backdrop to converse with those at the court 'as long as the dancing lasted'. ${ }^{21}$ As these examples indicate, Elizabeth played the joint roles of the observer with great power to bestow favour as well as the performer who was the object of observation.

But while performing had its benefits, being on display involved risks, and a clever monarch would have to know how to manage them. While Henry VIII performed for multiple audiences, Elizabeth's successor, James I, never danced or performed, keeping to the role of observer. James, aware of the scrutiny he had to endure in the public eye, wrote to his son in 1599 that a 'King is as one set on a skaffold, whose smallest actions $\&$ gestures al the people gazingly do behold'. While the word 'scaffold' seems to signify here more a place of action and performance than a place of execution, it none the less points to the dangers and the possibility of error that could occur in public. Unsurprisingly, according to Arthur Wilson, a contemporary observer, James 'did not love to be looked on' and consequently avoided those events 'which set a lustre upon Princes in the people's eyes. ${ }^{22}$ James's apparent physical weaknesses might have further impeded his desire to dance. But while James preferred to be an observer only, as king he often observed the representation of his more perfect self, portrayed by an actor in masque dances. ${ }^{23}$

James chose the safety of watching, but Elizabeth was willing to 'show herself in public', and accrue that 'lustre' in 'the people's eyes'. But she also knew that she needed to manage her public persona carefully. We have Elizabeth's own words on being in the public eye; when discussing the 'most 
grievous and irksome burden' of the execution of Mary Stuart, Elizabeth said that 'princes ... are set on stages in the sight and view of all the world duly observed. The eyes of many behold our actions; a spot is soon spied in our garments; a blemish quickly noted in our doings. ${ }^{24}$ Despite the risks of scrutiny that celebrity might bring, Elizabeth concluded that performing as a dancer could help construct an image of a competent and powerful ruler, one without blemish.

The queen seemed to manage the image of her dancing and the message about her person in the same way she controlled her portraits. ${ }^{25}$ Anthony Weldon records in his memoir a story about Sir Roger Aston, an Englishman raised in Scotland who served James I as a 'messenger' to Queen Elizabeth. Weldon says that whenever Aston went to England to 'deliver any letters' from James 'he was placed in the lobby, the hangings being turned him, where he might see the queen dancing to a little fiddle'. The strategy behind this visual presentation of a dancing Elizabeth is clear and Aston gets the message - that he should return to James and 'tell his master by her youthful disposition, how likely he was to come to the possession of the crown he so much thirsted after. ${ }^{26}$ The point of such a public relations move is to emphasize the continuing physical strength of the queen. Elizabeth uses a similar strategy with de Maisse, when she tells him, after some discussion of her dancing, 'I think not to die so soon, Master Ambassador, and am not so old as they think'. ${ }^{27}$

Baldassare Castiglione addresses the question of the benefits and risks of performance in his Book of the Courtier, published in 1528. Although ostensibly directed to the courtier, Castiglione's book was a best seller in the Renaissance, and men and women in and out of the court followed its advice about behaviour, conduct, political acumen, and construction and performance of the self. Castiglione describes the talents and characteristics ideally required for women and men, and in doing so he articulates the gender divide of the Renaissance. A man is expected to be strong, virile, accomplished, and 'versatile' in many things, 'surpassing the rest just a little in everything, so that he may always be recognized as superior.' ${ }^{28}$ The ideal female, on the other hand, should 'in no way resemble a man'; rather she should 'have a certain soft and delicate tenderness, with an air of feminine sweetness in her every movement'. ${ }^{29}$ Thomas Elyot echoes Castiglione's sentiments in his The Book Named the Governor (1531), when he describes men as 'fierce, hardy', and 'strong in opinion', and women as 'mild, timorous, tractable'. ${ }^{30}$ While Elizabeth as female is subject to many of Castiglione's and Elyot's 
recommendations, as a prince she manoeuvres between the two in the same way she negotiates between being the observer and the observed in dancing. The queen may not have wrestled or engaged in combat, as the male courtier and prince were expected to do, but she was certainly striving to 'surpass the rest' and be acknowledged as physically and mentally 'superior' in order to maintain control of her image, her power, and her reputation. ${ }^{31}$

Castiglione notes dancing among the 'various kinds of recreation' the courtier and prince can engage in both publicly and privately. Guicciardini, who had dismissed dancing and singing as 'frivolous' when he was younger, agrees that such 'accomplishments lend dignity, and reputation'. ${ }^{32}$ In Castiglione's book, Ottaviano Fregosa also raises the concern that dancing is 'vain and frivolous', but he too abandons these criticisms, conceding that dancing, along with other expected courtly skills, is 'most advantageous' when 'directed' to 'the virtuous end'. Elyot echoes Castiglione, arguing that dancing is 'an introduction' to and a 'meditation' on the 'first moral virtue' of prudence, where the very structure of dancing, its orderliness, its 'keeping just measure and time', is a model of prudence in action. But Elyot, making his strongest statement regarding the virtues of dancing, writes that those who have 'their courage stirred toward very honor or perfect nobility' should 'either themselves dance' or 'behold' those 'that can dance truly'. ${ }^{33}$ Dancing, then, is both a virtue in itself and a means to virtue. It leads to perfect nobility and if one desires such virtue, one must dance, or at least watch and learn from those who dance well.

But in order to realize the virtues of dancing and assure that it is 'most advantageous' to the courtier, Castiglione advises caution and control; the performer 'should take great care' when dancing in 'front of a crowd' in order to 'maintain a certain dignity'. Dignity is attained by managing the details of the time, place, occasion, and role of the performance so that, as Fregoso warns, the spectators 'are seeing what they are meant to imagine'. ${ }^{34}$ This last point seems particularly important advice because it speaks to how the dancer needs to control the perception of the dance. Elizabeth was apparently as careful about the occasions of her dancing as she was about how her image was projected, as the story of the tapestry demonstrates. In June 1600 , while watching a masque in honour of the wedding of Lord Herbert and Anne Russell, the queen was approached by Mrs Fetton who 'went to the Queen and woed her to dawnce'. But Elizabeth was cautious and asked Fetton what role she would be playing. When Mrs Fetton said 'Affection', the queen replied that 'Affection' is 'false'. 'Yet', the narrative continues, 'her 
Majestie rose and dawnced'. ${ }^{35}$ The report of this interchange, although brief, speaks to how well Elizabeth tried to implement Castiglione's advice and control her image as she danced 'in the sight of all'. Whatever her doubts, the queen chose to dance, perhaps deciding that such a display carried greater value than any possible negative association.

Elizabeth's caution and Castiglione's misgivings indicate how dancing could be dangerous to one's public image. While dancing was a popular entertainment for all classes, and while it might have benefitted those at court, if carefully managed, it certainly was not embraced by the entire society. On the contrary, dancing was subject to a great deal of criticism and attack. Philip Stubbes presents the general attitude of those who felt that dancing was less than a suitable pastime in The Anatomie of Abuses (1583), when he writes that dancing is an introduction to all kind of whoredom, a preparative to wantonness, a provocation to uncleanness, and an entrance to all kind of lewdness. ${ }^{36}$ John Northbrooke, Church of England clergyman, saw dance as a 'liberty to wantonness, a friend to wickedness, a provocation to filthy lust, enemy to chastity.' ${ }^{37}$ Stubbes gets to the heart of the dancing problem - its perceived sexual nature - when he demands 'what clipping, what culling, what kissing and bussing, what smouching and slabbering one of another what filthy groping and unclean handling is not practiced everywhere in these dancings' ${ }^{38}$

And while men as well as women came into the circle of condemnation, women were thought to be particularly vulnerable to the corruption of dancing. As William Prynne writes in 1633, the 'way to heaven is too steep, too narrow ... for capering roisters, for jumping, skipping, dancing dames. ${ }^{39}$ Queen Elizabeth herself was the object of such criticism in 1589 when a Parson Wylton 'spake openly in church' calling her an 'arrant whore', because 'the queen is a dancer', and according to Wylton's preaching, 'all dancers are whores. 40

Being called a whore was one of many difficulties that Elizabeth confronted during her reign as a female monarch. Throughout her forty-five years as queen Elizabeth faced questions about the legitimacy of her rule; foreign and domestic threats and possible invasion; the ongoing challenges from Scotland and Ireland; constant conflict between protestants and Catholics within her own country and the continuous threat of intervention from Catholic countries; pressure from within her own court regarding the question of marriage; threats against her life; and attacks because she was a female monarch. The doubts and fears about having a woman in power were in part 
responsible for remarks that Elizabeth was a dancing whore, and such doubts were also behind John Knox's First Blast of the Trumpet Against the Monstrous Regiment of Women (1558). ${ }^{41}$

Knox's polemic may not have been directed specifically at Elizabeth nor was it the only attack against her or female rule, but it is a useful text to cite because it articulates the major objections to women's rule. Knox's argument focuses on the idea that 'women' are 'utterlie forbidden to occupy the place of God' in public office, and 'usurpe authoritie over man'. Female rule is 'a thing repugnant to nature', he writes, because it perverts God's necessary order in which a woman's 'greatest perfection' was that she 'was created to be subject to man'. Knox further justifies his position by cataloguing the infirmities of women: they are 'weake, fraile, impacient, feble, and foolish ... unconstant, variable, cruell'. Paraphrasing Tertullian and echoing attacks on female dancers, Knox indicts women: 'Thou art the port and gate of the devil'. 42

Dredging up critics like Chrysostome, Knox argues that women are just not virtuous enough; they have within them 'a tickling and studie of vaineglorie'. He is particularly vexed by the visual images of a female in power, 'sitting in judgement or riding frome parliament in the middest of men, having the royall crowne upon her head, the sworde and scepter borne before her, in signe that the administration of justice was in her power'. ${ }^{43}$

Knox's Regiment gave voice to the perhaps common opinion about Elizabeth's power to rule. If we look to the records of some of the diplomats, usually foreign visitors to the English court sent to negotiate on issues from Elizabeth's potential marriage to cessation of conflicts, we see that their attitudes to the queen could range from enthusiastic praise to a critique that resembles Knox's. Both Bernardino de Mendoza, the Spanish ambassador writing to Philip II from Paris, and the duke of Parma, writing to Mendoza about the preparation for the planned Armada of 1588, refer to Elizabeth as 'the Englishwoman'. ${ }^{44}$ According to Ilona Bell, a careful look at some of these correspondences reveals 'misogyny and its hand maiden, the negative stereotype'. This assessment seems accurate in the correspondence of the count de Feria, who had been sent to England in 1559 to negotiate a marriage contract with Elizabeth for Philip of Spain. Expressing his frustration over Elizabeth's persistence that she meet any potential husband before agreeing to marry, Feria writes that Elizabeth is 'a very strange sort of woman'; at another time he wishes that 'that woman were to quite lose her head and bring matters to a point'. In the same passage Feria calls her 'a baggage', and his successor, Don 
Alvaro de la Quadra, dismisses her as 'a passionate ill-advised woman', and her position about marriage as 'nonsense'. 45

A close look at the first-person narratives of these diplomats uncovers the complexity of a political situation, freighted with internal and external threats and challenges and an atmosphere of intrigue, plotting, and deception at court, through which Queen Elizabeth had to negotiate her political safety and integrity. Despite the inherent misogyny of these attacks, politically and linguistically Elizabeth often triumphed over these foreign visitors and impressed them with her command of language. ${ }^{46}$ Count de Feria, frustrated and unable to convince the young queen to marry, 'asked to be released' from his mission and return to Spain. Daunted by the queen's verbal skills, he concluded from this experience that 'the English are cunning, and when of the mind can dupe others very easily. ${ }^{47}$ The Austrian ambassador, baron von Gundlfingen, praised Elizabeth's ability to speak 'extempore and with many brilliant, choice, and felicitous phrases'. And Virginio Orsini, who visited the court in 1600 , was so impressed with her skill at 'speaking Italian so well', that he felt he had been taking lessons 'from Boccaccio or in the Academy'. ${ }^{48}$

We are comfortable with the fact that Queen Elizabeth was verbally talented, that having control over the language in her speeches and letters, she was able to use 'her verbal powers to define her authority' and to gain 'a rhetorical advantage'. ${ }^{49}$ If we look at the language of Elizabeth's dancing, both in performance and in conversations about her dancing, we see the same 'authority' and 'rhetorical advantage' in her masterful linkage of the two discourses. Recall that in praising the queen's many talents, Alençon linked 'dauncing' with 'discoursing' and 'the perfection of many Languages'. Also recall Arbeau's idea of dancing as 'a kind of mute rhetoric', in which the dancer can make himself 'understood by his movements and persuade the spectators that he is gallant and worthy to be acclaimed, admired and loved. .50 Arbeau was not alone in this notion. Other early modern texts such as John Davies's poem Orchestra expound on the 'shared physicality' between dance and language, illustrating that 'while dance is linguistic, language is itself physical'.51

Elizabeth was clearly successful in using the rhetoric of her actual dancing as a linguistic and diplomatic strategy to manage the often treacherous reality of her court. I want to add, however, another dimension to this link between dancing and speech, and examine how Elizabeth was able to insinuate discussion of her dancing into conversations about important political issues. 
An examination of narratives written by James Melville, André de Maisse, and Virginio Orsini, reveals how Elizabeth, using the push-pull, innuendo, suggestion, and subtlety of negotiation, seamlessly blends the rhetoric of dancing with the rhetoric of language to gain political advantage, enhance the perception of her abilities, and convince observers that she was worthy of acclaim, admiration, and love. The fact that each of these narratives, including records of the members of her own court, preserve and comment on Elizabeth's dancing indicates that it was important enough to be written down and that, therefore, she needed to control what would be recorded.

In September 1564, Sir James Melville was sent to Elizabeth's court from Mary Queen of Scots for a nine-day visit regarding the improvement of relations between the two countries as well as the potential marriage of Mary to Elizabeth's favourite, Robert Dudley. Melville writes that he talked with Elizabeth 'every day, and sometimes thrice in a day'. ${ }^{52}$ Melville's descriptions of these conversations reveal how adept Elizabeth was at mixing political talk - the marriage between Mary and Dudley — with a kind of flirtatious banter in which Elizabeth manipulates Melville to compliment her. With regard to clothing, of which the queen says she has 'every sort', she asks 'which of them became her best'; comparing herself and Mary, she asks 'what color of hair was reputed best' and 'which of the two was fairest'. Elizabeth keeps at Melville, 'in earnest with me', he writes, to 'declare which of them I judged fairest'. He proves tactful, replying that Elizabeth is the 'fairest Queen in England and mine the fairest Queen in Scotland'. But Elizabeth persists, asking him then who has 'the highest stature', and who played 'upon the lute and the virginals' better. ${ }^{53}$

Melville relates how later that day after dinner, Lord Hunsdon 'drew' him up to a quiet gallery' where he 'might hear the Queen playing upon the virginals' behind a tapestry. The interesting aspect of this scenario is the pretence that both Melville and Elizabeth act out — she pretending to be 'surprised', ready to 'strike' him for sneaking in, 'alleging', as Melville writes, 'she used not to play before men' but did so to 'shun melancholy', and he apologizing that he in passing 'heard such melody as ravished' him that he was 'drawn in'. Melville, having to play his part in the drama, tries to take the 'occasion to press earnestly' his 'dispatch'. Elizabeth will not shift the conversation in the way Melville wants and takes his comment to mean he is bored with her. Although he writes how he informed Elizabeth that he needed to get back home to tend to Mary's 'affairs', he also reveals how he 'stayed two days longer, till I might see her dance', after which Elizabeth, in 
the same manner she employed to elicit the earlier compliments, used the occasion to ask him if she or Mary 'dances best'. He, tactful again, avoids her displeasure by replying that his queen 'danced not so high and disposedly as she did'. ${ }^{54}$ In essence, Elizabeth finally wins, getting Melville to grant her the advantage, and she does it around her dancing.

A number of elements within these negotiations are worth noting. One is how effectively the queen strategizes around the actual performance of her dancing. Manipulating Melville to remain at court to see her dance 'in the sight of all', as Arbeau noted, is really a visual and public triumph over the Scottish ambassador. And then in her subsequent conversation with him, the queen gets Melville to praise her for dancing and, by association, her successful manoeuvre. The conversation also includes Elizabeth's technique of seeming to avoid the political issue at hand by constructing a competition between herself and Mary and testing Melville to see how he will handle the challenge. Elizabeth does not ask Melville questions about who the best ruler is, but rather who dances best, plays music best, or has the most beautiful hair or skin, but the subtext is really about who is the most skilled, talented, and powerful ruler. Throughout Melville's narrative we see Elizabeth's mastery at weaving together the political with the seemingly trivial, keeping the ambassador ever on his guard, feigning shock at his listening to her play, ready to slap him for sneaking in on her, expressing dismay at his wanting to change the subject, getting him to tell her how beautiful, competent, and talented she is, all the while coercing him to insinuate the inferiority of his own queen. Elizabeth's dancing is a key element in these conversations, as she cleverly incorporates her actual dancing and musical abilities as well as the discussion of her dancing in a manoeuvre that presents herself as superior, while keeping Melville on his guard and herself in control.

André de Maisse, who came to the English court in 1597 on a special mission from King Henri IV of France to see if Elizabeth was willing to make peace with Spain, notes similar strategies in his journal. The French diplomat begins by criticizing the queen, but by the end he is praising her many talents, including her dancing. De Maisse's first impression of Elizabeth is that she is 'avaricious', 'haughty', and 'thinks highly of herself'. He makes a particular point of noting how, when speaking to a man who says 'something displeasing, she interrupts not seldom'. De Maisse ends his initial assessment with writing that she had a 'high opinion of her wisdom and prudence' and felt that she was 'intended for affairs of state. ${ }^{5}$ 
The ambassador gives much attention to the body and attire of Elizabeth. After one meeting, for example, he notes that she is in her 'nightgown', describing such details as her collar 'with little pendants of rubies and pearls'. More than once he offers details about her physical body, how often she would 'open the front' of her robe, 'as if she were too hot', how he was able to see her 'wrinkled' 'bosom', 'all her belly', and how 'lower down her flesh is exceeding white and delicate. ${ }^{56}$ Exactly what purpose such bodily details serve is difficult to know, but certainly Elizabeth calls attention to her physical self and her dancing throughout, as well as to her dress in early meetings, wondering what the 'gentlemen' who 'accompanied' de Maisse will 'say' 'to see me so attired'. 57

Such details possibly indicate that they share an intimate physical space, perhaps in one of the more private chambers, where on 24 December, de Maisse, like Melville, found himself in a kind of 'play', where the queen 'feigned surprise' as the French ambassador came upon her 'listening to the spinet played to her in her chamber'. She tells him that she loves 'music greatly', and that she 'was having a pavanne played', a popular, stately dance. On another evening, as they parted, he reports that 'she retired half dancing to her chamber. 58

On 6 January another staged event occurs, a drama in which de Maisse will have to play his part. De Maisse, told by a 'gentleman' that the queen would soon 'pass by with her ladies on her way to the dancing', encounters Elizabeth who, although 'it was she who had sent' the gentleman, pretends again to be surprised. Inviting de Maisse to accompany her to the gallery to watch the dancing, the two, sitting together, converse about her 'dancing and music', something in 'which she takes great pleasure' the ambassador writes. ${ }^{59}$ On this occasion de Maisse also observes how Elizabeth enjoys watching her ladies dance, although she chastises them if they make mistakes. The critique of the ladies' dancing, along with the queen's comments that 'in her youth she danced very well', had 'composed measures and music', and had 'played them herself and danced them', are all used to make herself the centre of the exchange as an accomplished musician and dancer. In fact, de Maisse concludes that Elizabeth is 'without a doubt a mistress of the art' of dance, having 'learnt in the Italian manner'; she tells him that the Italians call her 'the Florentine', and he, knowing his cue, replies that this 'was a sign that she was wise and discreet'; yet she denies this, saying 'she had never been' 'accomplished'. 60 
As this exchange reveals, Elizabeth's strategy with de Maisse is different from her banter with Melville when she was younger and tried to insinuate her superiority to Mary Stuart. This shift reveals Elizabeth's changing methods of self-presentation as she aged and as circumstances demanded. While she is always playing her major role of queen, that persona is not rigidly fixed; she innovatively adapts her dancing and discussion of her dancing to the occasion. In conversation with de Maisse she alternates between self-promotion and self-deprecation. 'She often called herself foolish and old', he writes. She apologizes to him, saying that after he had seen so many 'wise men and great princes', he had come to see a 'poor woman and a foolish'. But when he tells her that 'nothing' he had heard about her 'compared with what' he 'saw', she is 'contented'. This response is all part of the queen's plan since, as de Maisse writes, 'she is very glad to speak slightingly of her intelligence and sway of mind, so that she may give occasion to commend her'. ${ }^{61}$ Sounding a bit like John Knox, who called women 'fraile', 'feble', and 'foolish', she paints herself as weak and old, not as a talented dancer, denying de Maisse's compliment. But she does so as a way of showing how she is indeed strong, vigorous, and competent. Self-deprecation, fishing for compliments, feigning surprise, playing music, dancing, and digressing are all part of Elizabeth's arsenal of diplomatic performance techniques. The ambassador's journal, for example, records how she turns digression into a performance. 'She makes digression very often', he writes, entering 'upon several commonplaces' about marriages, how many languages she speaks, dancing, either to 'gain time and not to feel pressed', 'or because it is her natural way'. Commenting on the tactics of the English in general, de Maisse writes that in order to get anything from them he learned not to ask directly — 'a man who asks them for anything is a thousand times rebuffed'. The ambassador's patience, his ability to play his expected role and to wait, is finally rewarded when, as he records, while watching her ladies dance, and after the discussion about her own dancing, Elizabeth suddenly, and rather casually, says 'that she had given orders for her Council to assemble and I should go to it'. She also reveals that although she and de Maisse had been discussing the topic of peace and a meeting for a while, 'till that day she had not yet spoken' to the council. ${ }^{62}$

De Maisse's and Melville's narratives reveal the drama of these encounters, which is perhaps attributable in part to what Clare McManus has called 'the theatricality of aristocratic behavior in everyday social interaction. ${ }^{63}$ Perhaps the constant necessity of negotiation in court life demanded the theatrical. Elizabeth was certainly a consummate performer - a cunning actor, 
a talented musician and composer, an accomplished dancer. And she utilized all of these skills in conversation, in negotiation, and in constructing and maintaining a representation of herself as a competent and powerful ruler. Her self-presentation seemed to have worked with the French ambassador, who might have arrived in England critical of the queen, but who still had to admit that she is 'very beautiful', 'fair and tall and graceful in whatever she does', that 'she keeps her dignity', and that she 'is a very great princess who knows everything' ${ }^{64}$

In fact, the structure of the queen's conversations with de Maisse and Melville resembles in many ways the structure of a Renaissance dance. As McManus has pointed out, both 'court conversation' and dance could begin with the gesture of a bow, the 'reverence' or the 'honor', as Elyot calls it. Elizabeth's conversations with Melville and de Maisse seem to move as if governed and choreographed by the rules of dance. Beginning with the expected courtesy, they move through the prearranged steps, forward and return, all conducted in a 'mature' manner. 'Maturity', according to Elyot, is 'a mean between two extremities'; the dancer, knowing when the moment is 'ripe or ready', moves neither 'too swiftly nor slowly' but 'in due time and measure' until, the desired conclusion reached, the dance ends as it began, with a reverence. ${ }^{65}$ Dancing, a metaphorical representation of prudence, seems patterned on the gestures of human interaction, and Elizabeth seems to follow this pattern of prudence in her conversations, moving neither too fast, nor too slow, waiting for the 'ready' moment to make her move.

The moment of seeing the queen actually dance, her movements physically and publicly displayed, was a significant event. The lord chamberlain records that on Twelfth Night 1599, the queen, 'to close up the holidays, and to do the Danish ambassador honor, danced with the Earl of Essex, very richly and freshly attired'. ${ }^{66}$ Given the difficulties and challenges that Essex faced at court, challenges that eventually led to his execution in 1601, Elizabeth's dancing with him in this politically charged moment displayed to the court, particularly to his enemies, and to the Danish visitor, a sign that Essex had her support and favour, even if short-lived. ${ }^{67}$

Elizabeth's dancing was also intended to honour the Danish ambassador. This question of honour comes up again in one of the last mentions of Elizabeth dancing in January 1601 when 'shee entertained two Ambassadors and one Duke ... the Muscovy Ambassador, the Barbarian Ambassador and the Duke of Brachiano a Roman, whom the Queen entertained in al state, love and kindness, in whose presence her Royall person daunced, being then 
sixty-nine yeeres of age'.68 The duke of Bracciano was Virginio Orsini, who had met Lord Cecil in Florence in 1600. Cecil must have thought that Orsini, the cousin of the queen of France, the nephew of Grand Duke Ferdinando of Tuscany, and the relation of powerful cardinals, could be an important visitor to court. Orsini's 'imperial hosts in Belgium', furthermore, were convinced that Elizabeth was near death and worried that the event would cause chaos in England. ${ }^{69}$ Given Orsini's status, and the political concerns about Elizabeth's health, she likely would have wanted to impress Orsini with the stability, power, and splendour of her reign and court. She apparently succeeded; in two letters to his wife, Orsini records his brilliant experiences and his reception by the queen, writing that he 'seemed to have become one of those knights traveling in those enchanted palaces. ${ }^{70}$

On the feast of the Epiphany, Orsini was thrilled to see a comedy with 'music and dance'. He carefully notes the absence of the Muscovite ambassador and is most particularly thrilled to be 'always near her Majesty' who 'commands him to keep on his hat' and 'a thousand times to sit. ${ }^{71}$ Orsini, however, experienced his most splendid moment on 9 January, writing that 'Her Majesty was content to dance which is the greatest honor (il maggiore honore) that she was able to do for me', since, according to members of the court, she had not danced for fifteen years. ${ }^{72}$ While the record of Elizabeth dancing with Essex indicates that she had been dancing more recently, such a comment may well have been carefully calculated to make Orsini's experience of seeing her dance even more extraordinary.

The key word in Orsini's account seems to be 'honore', that it was a great honour that the queen danced for him in the same way she had given honour to the Danish ambassador. Was this great honour in part because Elizabeth had not been dancing publicly very often and because she was old? Perhaps, but recall that when she was much younger, Melville remained at court two days longer to see Elizabeth dance, implying that he stayed to honour her but also that it was a great honour for him to see her dance. Recall also Elyot's argument that anyone who has the 'courage' to 'be stirred toward very honor or perfect nobility' must dance, but if he cannot, he should at least 'behold with watching eyes' those that can 'dance truly'. Elyot's claim for the ennobling power of dance implies that dancing 'in the sight of all' goes beyond the expected role of political display to the realm of virtue for the beholder and the dancer. Those who can dance truly reveal to the observers the truth of an ideal that bestows honour and nobility. ${ }^{73}$ For Orsini and the others present, just watching the queen, who was much respected for her excellent ability 
to 'dance truly', was a complex and significant moment, bringing honour to Elizabeth, her court, and all those who beheld.

When the queen stepped onto the dance floor 'in the sight of all', she was also creating and enhancing a bond of trust between those with whom she had a special relationship. ${ }^{74}$ Politically, socially, materially, the queen and England had much to gain from the occasion, the dancing, and the presence of the visitors. Melville was the ambassador from Mary Stuart during a time of tensions between the two countries; de Maisse was on a special mission from France; and Orsini was very well connected - with the French, the pope, the imperial powers, and the Italian merchants in London. In fact, after the dance, Orsini, a Catholic, was invited to Elizabeth's 'closet over the chapel' where a 'Communion table', 'adorned' with 'ornaments', and maybe even a 'crucifix', had been set up. ${ }^{75}$ The dancing for Orsini seems a crucial part of an elaborate public relations display set in the splendid glitter of the court, charged with the anticipation of Elizabeth performing, enhanced by court gossip that she had not danced for fifteen years, all of which makes a statement in itself but also serves as the background and prelude to the politically charged communion table.

With regard to the political intentions of these dance events, the English description of Orsini's visit, 'A Commemoration of Queen Elizabeth' in Stow's Chronicles, adds a significant comment after mentioning that the queen 'hath been pleased to dance before him'. The English commentary continues that Orsini, 'as a well experienced courtier knew to make show of admiring her as most excellent and all her actions incomparable. ${ }^{76}$ As all of these narratives indicate, dancing was an occasion to admire and honour Elizabeth and her accomplishments, and the courtier, here Orsini — but including Melville, de Maisse, and others as well — was expected to play his part in the 'drama' to praise the queen and 'make show' of his admiration. The admiration, enthusiastically expressed at the moment, is then written down and recorded, guaranteeing the dissemination of Elizabeth's 'special vertues' 'approved and publiquely knowne to the whole world'. ${ }^{77}$

The commemoration also praises the queen for her 'excellent eare in Musicke', for her 'resolute and ... undaunted spirit', for her 'vertues' 'approved', for 'escaping manie daungers', and for her willingness to dance before Orsini, 'being then 69 yeeres of age'. ${ }^{78}$ Significantly, Elizabeth's dancing is listed with the greatness of her spirit, her internationally famous persona, and her escapes from danger. What is clear from these accounts written during her life and after her death is how successful Elizabeth was in employing certain 
strategies, including her dancing, to construct a lasting image of herself as a virtuous, noble, youthful, strong, brave, and competent leader who contradicted Knox's indictment that women could not rule because they 'lacke prudent and right reason'. ${ }^{79}$ The queen's dance strategies and her manipulation of the discourses around her dancing demonstrate that Elizabeth took an aggressive approach to the dangers and challenges she faced as a female ruler. They also demonstrate that she was a savvy politician who used performance and the rhetorics of dancing and speaking to fashion and maintain an image of herself 'in the sight of all', and convince those who beheld her that she was certainly worthy of 'great satisfaction and admiration'. ${ }^{80}$

\section{Notes}

1 Regarding the dancing couple, Roy Strong mentions that this painting is from the Valois Court, c 1580, and concludes that the dancer is not Elizabeth. See Portraits of Queen Elizabeth I (Oxford, 1963), 48. The De L'Isle family, on the other hand, which owns Penshurst Place, where the picture is on display, maintains that this is indeed Elizabeth and Dudley. Peter Holman, Four and Twenty Fiddlers: The Violin at the English Court, 1540-1690 (Oxford, 1993), 116, says the painting is unlikely to be an accurate depiction of an event at the English court, since it is ... similar' to paintings from the Valois court. Holman adds that 'the Penshurst picture is an English variation on a French theme ...; the fashions shown are compatible with those worn at the French and English courts around 1580'.

2 Robert Naunton, Fragmenta Regalia or Observations on Queen Elizabeth: Her Times and Her Favorites (1630) (Washington, D.C., 1985), 67. See G.B. Harrison, A Last Elizabethan Journal (London, 1933), for a 1595 performance of the 'masque of Proteus' by the men of Gray's Inn for the queen at court.

3 John Nichols, The Progresses, Processions, and Magnificent Festivities of King James the First (London, 1828), 1.185.

4 Clare McManus, Women on the Renaissance Stage: Anna of Denmark and Female Masquing in the Stuart Court (Manchester, 2003), 25.

5 Jennifer Nevile (ed.), Dance, Spectacle, and the Body Politick, 1250-1750 (Bloomington, IN, 2008), 12.

6 Barbara Ravelhofer, The Early Stuart Masque: Dance, Costume, and Music (Oxford, 2006), 266.

7 For the role of performance, dance, and politics in European courts, particularly with regard to the court masques, see Enid Welsford's major work on the court 
masque: The Court Masque: A Study in the Relationship between Poetry and the Revels (Cambridge, 1927). See also Sydney Anglo, Spectacle, Pageantry, and Early Tudor Policy (Oxford, 1969); Stephen Orgel, The Illusion of Power: Political Theater in the English Renaissance (Berkeley, 1975); David Bevington and Peter Holbrook (eds), The Politics of the Stuart Masque (Cambridge, 1998); Skiles Howard, The Politics of Courtly Dancing in Early Modern England (Amherst, MA, 1998); Jennifer Nevile, The Eloquent Body: Dance and Humanist Culture in Fifteenth-Century Italy (Bloomington, IN, 2004); Nevile (ed.), Dance, Spectacle; Sophie Tomlinson, Women on Stage in Stuart Drama (Cambridge, 2005); Ravelhofer, The Early Stuart Masque; Martin Butler, The Stuart Court Masque and Political Culture (Cambridge, 2008); and Margaret McGowan, Dance in the Renaissance: European Fashion, French Obsession (New Haven, 2008).

8 For a discussion of Queen Elizabeth and masques encouraging marriage presented to her in the mid-1560s, see Susan Doran, 'Juno Versus Diana: The Treatment of Elizabeth's Marriage in Plays and Entertainments, 1561-1581', Historical Journal 38 (1995). See also Barbara Ravelhofer, 'Dancing at the Court of Elizabeth', Christa Jansohn (ed.), Queen Elizabeth I: Past and Present (Piscataway, NJ, 2005); Alan Brissenden Shakespeare and the Dance (London, 1981); Howard, The Politics of Courtly Dancing; and Peter Holman, Four and Twenty Fiddlers.

9 Tomlinson, Women on Stage, 2. Tomlinson discusses the theatrical contribution of Anne of Denmark, Henrietta Maria, and other female performers as the steps toward women on the public stages.

10 Thoinot Arbeau, Orchesography, 1588, trans. Mary Stewart Evans (New York, 1967), 16. For other dance manuals, see, for example, Robert Coplande, The Maner of Dauncynge of Bacedaunces After the Use of Fraunce of Other Places 1521 (Sussex, 1937); Fabritio Caroso, Nobilità di dame, 1600, trans. Julia Sutton (New York, 1995); John Playford, The English Dancing Master, or Plaine and Easie Rules for the Dancing of Country Dances (London, 1651).

11 McGowan, Dance in the Renaissance, 128, 130, 132, 248. See also Nevile (ed.), Dance, Spectacle. For work on Catherine de Medici, see Frances Yates, The Valois Tapestries (1959; rpt London, 1999); R.J. Knecht, Catherine de' Medici (London, 1998).

12 Edward Hall, Hall's Chronicle (1548; London, 1809), 515-6. John Stevens, Music and Poetry in the Early Tudor Court (Cambridge, 1961), 244-5.

13 John Nichols, The Progresses and Public Processions of Queen Elizabeth (London, 1823), 1.239; Rawdon Brown and G. Cavendish Bentick (eds), Calendar of State Papers Relating to English Affairs in the Archives of Venice (London, 1890), 11, 16 June, 
1559, 7.108, 110; Victor von Klarwill (ed.), Queen Elizabeth and Some Foreigners (London, 1928), 338, 7.

14 Calendar of State Papers ... Venice, 2 January 1559, 7.5; Calendar ... Venice The Venetian, Il Schifanoya, 6 February 1559, 7.18.

15 John Stow, Chronicles, The Annales or General Chronicle of England, begun by maister John Stow, and after him continued and augmented ... this present year 1614. By Edmond Howes (London, 1615), 813.

16 Edmund Lodge (ed.), Illustrations of British History, Biography, and Manners in the Reigns of Henry VIII, Edward VI, Mary, Elizabeth, \& James I (London, 1853), 2.386.

17 G.B. Harrison (ed.), A Journal of All That Was Accomplished by Monsieur de Maisse, Ambassador in England from Henry IV to Queen Elizabeth, Anno Domini, 1597 (London, 1931), 94; Ravelhofer, 'Dancing at the Court of Queen Elizabeth', 109.

18 Arbeau, Orchesography, 18. For women, dancing, and the gaze see also Bella Mirabella, 'Mute Rhetorics: Women, Dance, and the Gaze in Elizabethan England', Genre 28 (winter, 1995).

19 John Schikowski, Geschichte des Tanzes (Berlin, 1926), 92. The translation is in Mark Franko, The Dancing Body in Renaissance Choreography 1416-1589 (Birmingham, AL, 1986), 33.

20 Francesco Guicciardini: Selected Writings, trans. Margaret Grayson (Oxford, 1965), 45.

21 Calendar of State Papers ... Venice, 16 June 1559, 7.101; de Maisse, A Journal, 94; Klarwill (ed.), Queen Elizabeth, 338.

22 James I, Basilikon Doron, (London, 1599), 121; John Nichols, The Progresses of James I (London, 1828), 1.327.

23 Anthony Weldon described him as having 'weak' legs that 'made him ever leaning on other men's shoulders', in Francis Osborne (ed.), Weldon's Court and Character of King James in Historical Memoirs of the Reigns of Elizabeth and King James (Edinburgh, 1811), 1.300. Represented as an allegorical figure in many court spectacles, James watched himself portrayed as a far more splendid figure than he was in real life. See McManus, Women on the Renaissance Stage 150, 145.

24 Leah S. Marcus, Janel Mueller, and Mary Beth Rose (eds), Elizabeth I, Collected Works (Chicago, 2000), 194. Mary was executed in 1587.

25 A 1596 act of the privy council condemns the 'abuse' of 'unskilled artisans in unseemly and improper painting' of 'her Majesty's person and visage to her great offence' and confirms that only those paintings that the queen's sergeant painter approves shall be 'allowed'. See John Roche Dasent (ed.), Acts of the Privy Council (London, 1900), xxiv, 69.

26 Osborne (ed.), Weldon's Court and Character, 318. 
27 de Maisse, A Journal, 82.

28 Baldesar Castiglione, The Book of the Courtier, trans. George Bull (London, 2003), 62.

29 Castiglione, Courtier, 211.

30 Thomas Elyot, The Boke Named the Governor, 1531, ed. S.E. Lehmbert (New York, 1962), 77-8.

31 See Mary Beth Rose, Gender and Heroism in Early Modern English Literature (Chicago, 2002), for a similar position regarding Elizabeth's ability to create 'her heroic personality by monopolizing all gendered positions', 27.

32 Guicciardini, Ricordi, 45.

33 Castiglione, Courtier, 284; Elyot, Governor, 79. Elyot writes that according to Aristotle, prudence is the 'mother of virtues'. For further discussion of the connection between dance and virtue, see Howard, Politics of Courtly Dancing; John Major, 'The Moralization of the Dance in Elyot's Governour', Studies in the Renaissance 5 (1958).

34 Castiglione, Courtier, 117-9, advises avoiding 'quick movements of the feet and double steps', which might prove 'unsuitable' and damage the dancer's image.

35 Nichols, The Progresses ... of Queen Elizabeth, 3.498-9.

36 Philip Stubbes, The Anatomie of Abuses, 1583, ed. Margaret Jane Kidnie (Tempe, AZ, 2002), 215.

37 John Northbrooke, A Treatise Wherein Dicing, Dauncing, Vaine Playes or Enterluds ... Are Reproved, 1577 (London, 1843), 135.

38 Stubbes, Anatomie, 217.

39 William Prynne, Histriomastix (London, 1633), 348. The literature denouncing dance is substantial. See Christopher Fetherstone, A Dialogue Against Light, Lewd and Lascivious Dauncing (London, 1582); Stephen Gosson, The Schoole of Abuse, Containing a Pleasaunt Invective Against Poets, Pipers, Plaiers, Jesters, and such Like Caterpillars of a Commonwealth (London, 1579). For modern analysis see Ann Wagner, Adversaries of Dance: From the Puritans to the Present (Urbana 1997); Jonas Barish, The Anti-Theatrical Prejudice (Berkeley, 1981).

40 Joel Samaha, 'Gleanings from Local Criminal-Court Records: Sedition Amongst the "Inarticulate" in Elizabethan Essex', Journal of Social History 8 (summer, 1975), 69; Carole Levin, The Heart and Stomach of a King: Elizabeth I and the Politics of Sex and Power (Philadelphia, 1994), 83.

41 John Knox, First Blast of the Trumpet Against the Monstrous Regiment of Women, ed. Edward Arber (London, 1878), 11.

42 Knox, First Blast, 15, 17-18, 12. 
43 Ibid, 24, 12. For other attacks on Elizabeth see, for example, John Stubbs, The Discoverie of a Gaping Gulf Where Into England is Like to Be Swallowed by Another French Mariage, 1579, in Lloyd E. Berry (ed.), John Stubbs's Gaping Gulf with Letters and Other Relevant Documents (Charlottesville, VA, 1968). See also Julia M. Walker (ed.), Dissing Elizabeth: Negative Representations of Gloriana (Durham, NC, 1998) for essays on critical views of the queen.

44 J.M. Rigg (ed.), Calendar of State Papers, Relating to English Affairs Preserved Principally at Rome, in the Vatican Archives and Library (London, 1916-1926), 19, 70. See also Martin A.S. Hume (ed.), Calendar of State Papers Simancas, 1892 (Nedeln, Liechtenstein, 1971), 4: 1587-1603, 24 Jan. Paris Archives, K. 1566. 33, in which Mendoza uses the term 'Englishwoman' three times.

45 Ilona Bell, 'Elizabeth I, Always Her Own Free Woman', Carole Levin and Patricia Ann Sullivan (eds), Political Rhetoric, Power, and Renaissance Women (Albany, 1995), 69; Hume, Simancas, 1.12, 102, 106.

46 As Ilona Bell remarks, Elizabeth was 'remarkably outspoken for a woman' and 'celebrated for her rhetorical and linguistic powers'. See Elizabeth I: The Voice of a Monarch (New York, 2010), 7, for a thorough examination of Elizabeth's linguistic prowess and a further discussion of Elizabeth's negotiations with foreign diplomats.

47 Bell, 'Elizabeth I', 69.

48 von Klarwell (ed.), Queen Elizabeth, 68; Michael Wyatt, The Italian Encounter with Tudor England: A Cultural Politics of Translation (Cambridge, 2005), 132.

49 Rose, Gender and Heroism, 27.

50 Arbeau, Orchesography, 16. See also Michel de Montaigne's comment that there 'is no movement that does not speak both a language intelligible without instruction, and a public language', Donald Frame (trans.), The Complete Essays of Montaigne (Stanford, 1958), 332. See also Mark Franko, The Dancing Body in Renaissance Choreography 1416-1589 (Birmingham, AL, 1986), 14-7; Contemporary dance theorist Judith Hanna writes that dance is a code that needs to be interpreted: the 'dancer (encoder) makes ideas and feelings known to another (decoder)', Dance, Sex, and Gender: Signs of Identity, Dominance, Defiance and Desire (Chicago, 1988), 5.

51 McManus, Women on the Renaissance Stage, 38-9. See also John Davies, Orchestra, or a Poem of Dancing 1596, ed. E.M.W. Tillyard (London, 1947).

52 E. Francis Steuart (ed.), Memoirs of Sir James Melville of Halhill 1633 (London, 1929), 92.

53 Ibid, 95-6.

54 Ibid, 96.

55 de Maisse, A Journal, 3. 
56 Ibid, 24-5, 37, 25. See Hannah Betts, 'The Pornographic Blazon 1588-1603', Julia M. Walker (ed.), Dissing Elizabeth, 176, for remarks about the de Maisse encounter.

57 de Maisse, 24-5.

58 Ibid, 55, 39.

59 Ibid, 91.

60 de Maisse, A Journal, 94, 95.

61 Ibid, 37-8.

62 Ibid, 109, 58, 115, 95.

63 McManus, Women on the Renaissance Stage, 20.

64 de Maisse, A Journal, 38, 26, 61.

65 Regarding the reverence, McManus, Women on the Renaissance Stage, 38-9, writes that the 'active presence of the human body in early modern performance' points to shared gestures within the discourses of dance and oration, such as the reverence, the bow of courtesy, which 'opened both court conversation and dance'.

66 Walter Bourchier Devereux (ed.), Lives and Letters of the Devereux, Earls of Essex in the Reigns of Elizabeth, James I, and Charles I 1540-1646. 2 vols (London, 1853), 1.8 .

67 For further discussion of the woes of Robert Devereux, second earl of Essex, see, for example, Lytton Strachey, Elizabeth and Essex: A Tragic History (London: 1940, 2012); J.P.G. Hammer, The Polarisation of Elizabethan Politics: The Political Career of Robert Devereux, 2nd Earl of Essex 1585-1597 (Cambridge, 1999); Richard McCoy, The Rites of Knighthood (Berkeley, CA, 1989).

68 John Stow, Chronicles, 815.

69 According to Michael Wyatt, Orsini 'was the only Italian of his station' to visit the English court. The Italian Encounter, 131.

70 Ibid.

71 Ibid, 133.

72 Ibid.

73 Elyot, Governor, 79. The reverence gesture that initiated a set of dances was also called the honour.

74 See Skiles Howard, The Politics of Courtly Dancing, 30-1, for the redefinition of honour from only being 'won by brave deeds' to a focus on dance and 'adroit manners and tractable bodies that promoted princely trust and social acclaim'. For a discussion of the honour curtsey, reverence, and honour and dance with regard to hierarchy and social order, see Howard, 31-5 as well as McManus, Women on the Renaissance Stage.

75 Harrison, Last Journal, 138.

76 Stow, Chronicles, 813. 
77 Ibid.

78 Ibid.

79 Knox, Regiment, 24.

80 Stow, Chronicles, 815. 